\title{
TEORI KONVERGENSI DALAM PRESPEKTIF PENDIDIKAN ISLAM KAJIAN PERKEMBANGAN KEPRIBADIAN DALAM RANGKA PEMBANGUNAN SUMBERDAYA PENEGAK HUKUM DI INDONESIA
}

\author{
Mashur Alhabsyi, S.Pd ${ }^{1}$ \\ Email: mashuralhabsyi5@gmail.com
}

\begin{abstract}
Islamic education on convergence theory is based on the concept of Hablummiallah (relationship with Allah), in the sense that it is Allah who gives the initial potential so that in Islamic education that personality must be formed and developed for ma'rifatullah (knowing Allah) and fearing Allah even apart from believing in that internal (innate) and external (environmental) factors are very influential in education, and form a quality Muslim personality. So the most important thing is to acknowledge guidance from Allah as a determinant of success in education and Hablumminannas (relations with humans) as a form of change in human personality in social or environmental life, with the formation of human beings who are sure to make state apparatus aware of the law and able to become pioneers upholding the law in Indonesia.
\end{abstract}

Keywords: Conversion Theory, Education, Law Enforcement

\begin{abstract}
Abstrak
Pendidikan Islam terhadap teori konvergansi, berpatokan pada konsep Hablummiallah (hubungan dengan Allah), dalam artian bahwa Allah lah yang memberikan potensi awal sehingga dalam pendidikan Islam kepribadian itu harus dibentuk dan dikembangkan untuk ma'rifatullah (mengenal Allah) dan bertakwa kepada Allah bahkan Selain meyakini bahwa faktor internal (bawaan) dan eksternal (lingkungan) sangat berpengaruh dalam pendidikan, dan membentuk kepribadian muslim yang berkualitas. Maka yang terpenting adalah harus mengakui hidayah dari Allah sebagai penentu keberhasilan dalam pendidikan dan Hablumminannas (hubungan dengan manusia) sebagai wujud perubahan kepribadian manusia dalam kehidupan sosial atau lingkungan, dengan terbentuknya Manusia yang taan tentunya akan menjadikan insan aparatur negara yang sadar hukum serta mampu menjadi pelopor tegaknya hukum di Indonesia.

Katakunci: Teori Konvergansi, Pendidikan, Penegakkan Hukum
\end{abstract}

\section{A. PENDAHULUAN}

Setiap pribadi manusia itu memiliki corak perilaku lahiriah dan rohaniah yang berbeda, hal ini muncul disebabkan setiap anak yang dilahirkan memiliki potensi

\footnotetext{
${ }^{1}$ Jaringa Advokasi Untuk Keadilan (JATI CENTRE) Sulawesi Tengah.
} 
bawahan. Dan potensi bawahan yang dimaksud yaitu potensi fitrah, sehingga makna fitrah memberikan potensi dasar manusia yang dibawah sejak lahir dan merupakan hasil pemahaman secara konseptual. Sehingga Ibnu Taimiyah sebagaimana dikutip oleh Muhaimin dan Abdul Mujib menjelaskan pembagian fitrah manusia menjadi dua macam;

1. Fitrah Almunazzalah yaitu fitrah luar yang masuk pada diri manusia. Fitrah ini berupa petunjuk al-Qur'an dan al-Sunnah yang digunakan sebagai kendali dan pembimbing bagi fitrah al-Garizah.

2. Fitrah al-Garizah yaitu fitrah inheren dalam diri manusia yang berguna untuk mengembangkan potensi dasar manusia. ${ }^{2}$

Untuk mendukung konsep fitrah di atas, maka dibutuhkan proses pendidikan. Karena pendidikan mempunyai peranan yang sangat strategis dalam mengembangkan kepribadian anak. Akan tetapi proses pendidikan yang dimaksud adalah suatu proses yang sudah direncanakan dengan baik, Yaitu dengan cara mendidik anak ke arah dan tujuan yang membawanya pada pemahaman tentang hakikat kepribadian dirinya sebagai manusia yang dapat berprilaku konsisten dalam berfikir, berbuat dan bersikap sepanjang waktu. Sebagaimana dikatakan oleh Prof. H. Muzayyin Ariffin dalam bukunya Filsafat Pendidikan Islam "Sifat-sifat yang unik atau istimewa yang menggejala dalam tingkah laku seseorang yang memiliki kepribadian tertentu, menggambarkan aspirasi dan arah tujuan tertentu, sehingga dengan mengamati dalam jangka panjang kita dapat melihat bahwa seorang itu telah memiliki pandangan hidup. Pandangan hidup itu berlangsung dalam perilakunya yang konsisten dalam berfikir, berbuat, dan bersikap sepanjang waktu". ${ }^{3}$

Panjelasan di atas memberikan gambaran bahwa setiap anak itu memiliki arah dan tujuan kehidupan masing-masing dengan potensi kepribadiannya dan pandangan hidupnya, karena adanya bakat dan pengalamanya sehingga akibat dari perpaduan antara bakat dan pengalaman itulah sebenarnya yang mempengaruhi terbentuknya corak kekhususan dari kepribadian seorang anak. Sebagaimana yang dikemukakan oleh Keogh dan Pfiffner yang dikutip oleh Eva Latipah bahwa "Kepribadian merupakan

\footnotetext{
${ }^{2}$ Muhaimin dan Abdul Mujib, Pemikiran Pendidikan Islam, (Bandung :TrigendaKarya, 1993), h. 21.

${ }^{3}$ Muzayyin Arifin, Filsafat Pendidikan Islam, (Jakarta: PT Bumi Aksara, 2012), h. 150.
} 
kecenderungan umum untuk merespons dan menangani peristiwa-peristiwa lingkungan dengan cara tertentu, karena setiap anak memiliki kepribadian yang unik dan khas sejak lahir". ${ }^{4}$ Kepribadian yang unik dan khas yang dimiliki seorang anak sejak lahir dapat mengenal berbagai macam aspek kehidupan dan nilai-nilai atau norma-norma yang berlaku dalam masyarakat dengan melalui pendidikan. Sebagaimana dikatakan oleh Jalaludin dan Abdullah bahwa, "Pendidikan berkaitan dengan usaha untuk mengubah sikap dan tingkah laku. Sedangkan kepribadian berhubungan dengan pola tingkah laku". ${ }^{5}$

Senada dengan itu, maka pendidikan Islam menawarkan konsep tujuan untuk membimbing anak agar berkembang menjadi manusia yang berkepribadian muslim dan muslimat yang shaleh atau yang takwah, serta membentuk jasmani dan rohani berdasarkan hukum-hukum agama Islam yang terbentuk dalam kepribadian ajaran Islam. Sebagaimana dikatakan oleh Munarji "Ada 3 (tiga) unsur yang mendukung tegaknya Pendidikan Islam, pertama harus ada usaha yang berupa bimbingan bagi pengembangan potensi jasmani dan rohani secara berimbang. Kedua, usaha tersebut berdasarkan atas ajaran Islam. Ketiga, usaha tersebut bertujuan agar peserta didik pada akhirnya memiliki kepribadian utama menurut ukuran Islam (kepribadian muslim).”6

Dari pandangan pendidikan Islam di atas bertambah jelaslah bagi kita, bahwa pendidikan Islam benarlah merupakan usaha bimbingan yang ditujukan untuk mencapai keseimbangan jasmani dan rohani menurut ajaran Islam, untuk mengarahkan dan mengubah tingkahlaku individu dalam mencapai pertumbuhan kepribadian yang sesuai dengan ajaran Islam dalam proses kependidikan melalui latihan-latihan kecerdasan, kejiwaan, keyakinan, kemauan dan persamaan dalam seluruh aspek kehidupan manusia. Dan bimbingan tersebut dilakukan secara sadar dan terus menerus yang sesuai dengan fitrah dan kemampuan ajarannya baik secara individual maupun kelompok, sehingga manusia mampu memahami, menghayati dan mengamalkan ajaran Islam secara utuh dan bulat.

Pada dasarnya pendidikan Islam tidak dapat dilepaskan dari fungsi pendidikan secara keseluruhan, yaitu untuk membentuk kepribadian berlandaskan moral. Sesuai

\footnotetext{
${ }^{4}$ Eva Latipah, Pengantar Psikologi Pendidikan, (Yogyakarta: PT Pustaka Insan Madani, 2012), h. 236. 5Jalaludin dan Abdulllah, Filsafat Pendidikan, (Jogjakarta: Ar Ruzz Media, 2012), h. 190.

${ }^{6}$ Munarji, Ilmu Pendidikan Islam, (Jakarta: PT Bina Ilmu, 2004), h. 6-7.
} 
dengan fungsi tersebut pendidikan agama menduduki posisi penting sebagai media elementer pembentukan watak, kepribadian dan karakter bangsa. Kalau kita melihat kembali pengertian pendidikan Islam, akan terlihat dengan jelas sesuatu yang diharapkan terwujud setelah seseorang mengalami pendidikan Islam secara keseluruhan, yaitu kepribadian seseorang yang membuatnya menjadi "insan kamil" dengan pola takwa. Insan kamil artinya manusia utuh rohani dan jasmani, dapat hidup dan berkembang secara wajar dan normal karena takwanya kepada Allah swt. Oleh karena itu, pendidikan serta pembinaan budi pekerti yang sesuai dengan ajaran agama Islam perlu diintensifkan sehingga dapat dijadikan pegangan bagi anak-anak serta remaja yang tentu saja kondisi jiwanya masih labil. Senada dengan pandangan di atas, Prof Muhaimin Dkk mengemukakan Ada dua arti penting dari defenisi pendidikan Islam yaitu Pertama pendidikan Islam merupakan aktivitas pendidikan yang diselenggarakan atau didirikan dengan hasrat dan niat untuk menjalankan ajaran dan nilai-nilai Islam dan kedua pendidikan Islam adalah sistem pendidikan yang dikembangkan dari dan disemangati atau dijiwai oleh ajaran dan nilai-nilai Islam. ${ }^{7}$

Pandangan pendidikan Islam di atas, saat dicermati lebih berfokus pada nilainilai ajaran Islam. Sehingga dapat menjadikan generasi yang beriman dan bertakwa kepada Allah swt. Hal ini berbeda dengan usaha yang dilakukan oleh para pemikir tentang berbagai upaya dalam pembentukan kepribadian anak, mereka diwarnai dengan perbedaan dalam dimensi ideologi. Dalam dunia pendidikan khusunya wilayah psikologi pendidikan, ada beberapa aliran yang mempengaruhi tingkah laku manusia, dengan pandangan teorinya mereka di antaranya adalah Nativisme yang lebih memfokuskan perkembangan seorang anak pada pembawaannya sejak lahir sedangkan pada faktor lingkungan berlandaskan pada teori Empirisme yang lebih memfokuskan perkembangna anak pada situasi lingkungannya. Hal ini seperti diungkapkan oleh Purwa Atmaja Prawira bahwa "Teori Nativisme mengatakan bahwa perkembangan anak tergantung dari pembawaan si anak yang bersangkutan. Jika anak berpembawaan cerdas, ia akan berkembang menjadi anak yang cerdas. Sebaliknya, jika anak pembawaan bodoh, ia akan berkembang menjadi anak yang bodoh. Sementara itu, teori

\footnotetext{
${ }^{7}$ Muhaimin, Suti'ah dan Sugeng Listyo Prabowo, Manajemen Pendidikan, (Cet III; Jakarta: Prenada Media Group, 2011), h. 3-4.
} 
ini bertolak belakang dengan teori Empirisme, Empirisme mengatakan bahwa perkembangan anak tergantung dari faktor luar (lingkungan). Perkembangan anak bisa menjadi apa saja tergantung faktor-faktor luar (lingkungan) yang akan mempengaruhi si anak." 8

Dari kedua pandangan di atas terlihat sangat kontradiktif dalam mengembangkan kepribadian seorang anak, sehingga kedua aliran tersebut dapat diistilahkan yang pertama dianggap sebagai tesa, maka yang kedua merupakan antitesa. Dan adapun sintesa dari kedua aliran tersebut adalah Konvergensi. Sehingga penulis mencoba untuk mengulas teori Konvergensi yang di pelopori oleh William Stern yang memadukan antara Nativisme dan Empirisme. Dalam kajiannnya Stern mengemukakan dalam deskriptif intelegensi (kecerdasan) seorang anak bahwa :

Intelligence is a general capacity of an individual consciously to adjust his thinking to new requirements:is general mental adaptability to new problems and conditions of life.

Kecerdasan adalah kapasitas umum dari kesadaran individu untuk menyesuaikan pemikirannya terhadap hal-hal yang baru: itu adalah adaptasi mental yang umum untuk masalah dan kondisi kehidupan. ${ }^{9}$

Dari pandangan yang dikemukkan oleh William stern secara implisit mendeskripsikan teori konvergensinya, sehingga kecerdasan yang dimaksudkan diatas tidak akan berkembang ketika tidak menyesuaikan pemikirannya terhadap hal-hal yang baru, maka sorang anak harus beradaptasi dalam kondisi kehidupan. Hal ini jelas terdapat perpaduan antara bawaan dan lingkungan sehingga Purma Atmaja Prawira mengemukakan bahwa "perkembangan anak ditentukan atau dipengaruhi oleh kekuatan dari pembawaan dan kekuatan pengaruh lingkungan disekitarnya. Teori Konvergensi perkembangan anak memberikan prinsip-prinsip bahwa perkembangan anak merupakan perpaduan antara kekuatan faktor dari dalam diri anak yang bersangkutan (pembawaan) dan kekuatan faktor luar (lingkungan), misalnya pendidikan yang baik yang diberikan kepada anak."10

Teori yang dikemukakan Stern di atas memberikan inspirasi bagi penulis untuk mengkaji lebih dalam tentang pengaruh teori Konvergensi tersebut. Karena saat 2013), h. 96

${ }^{8}$ Purma Atmaja Prawira, Psikologi Pendidikan Dalam Prespektif Baru, (Yogyakarta : Ar-ruzz Media,

9 William Stern, The Psychological Methods of Testing Intelligence, (Breslau: Baltimore Warwick \& York, Inc.1914), h. 3.

${ }^{10} \mathrm{Ibid}$, h. 97. 
mencermati teori konvergensi ini, maka tuntutan dalam pendidikan tidak hanya dapat didefenisikan sebagai pewarisan atau penanaman nilai-nilai dari generasi terdahulu kepada generasi yang datang kemudian, melainkan juga harus disertai dengan pemberian kesempatan yang seluas-luasnya kepada peserta didik untuk mengaktualisasikan dan mengekspresikan segenap daya dan kemampuannnya melalui penciptaan lingkungan yang kondusif.

Dalam teori Konvergensi ini dapat difahami bahwa pendidikan yang dilakukan di lingkungan itu mendapat peran yang sewajarnya dan pembawaan juga mendapatkan perhatian yang sewajarnya pula. Bahkan pendidikan dalam teori Konvergensi ini dapat diartikan sebagai pertolongan yang diberikan kepada anak didik untuk mengembangkan pembawaan yang baik dan mencegah pembawaan yang buruk. Karena hasil pendidikan amat ditentukan oleh hasil pembawaan dan lingkungan."

Pandangan di atas memberikan pengaruh sangat penting dalam kaitannya dengan pengembangan pribadi anak baik dari faktor pembawaan maupun faktor lingkungan. Hal itu untuk menggali dan memompa atau menggembleng diri dalam menyelami potensi yang dimiliki. Karena hematnya faktor bawaan dan lingkungan sama-sama memainkan peran dalam proses pembentukan kepribadian. Kedua faktor tersebut merupakan ikatan tali temali yang selalu bergandengan satu sama lain. Sehingga dalam pembentukan kepribadian harus ada singkronisasi yang baik dari kedua faktor tersebut. Dengan demikian diharapkan akan menghasilkan generasi yang unggul dan berkepribadian dengan nilai-nilai Islam. Berdasarkan pokok-pokok pikiran yang dikemukakan di atas, penulis melihat ada kesamaan konsep yang terdapat pada pendidikan Islam dan teori konvergensi William Stern dalam membentuk kepribadian anak.

Dengan demikian penulis tertarik untuk mengulas Konvergensi dalam Prespektif pendidikan Islam (kajian Pembentukan Kepribadian Anak) dengan beberapa sub Pembahasan yaitu Pertama Pengaruh Aliran Konvergensi dalam pendidikan. Kedua, pandangan pendidikan Islam terhadap teori konvergensi. Ketiga, relevansi teori konvergensi dengan pendidikan Islam.

\section{$251-252$.}

${ }^{11}$ Abudin Nata, Pemikiran Pendidikan Islam dan Barat, (Jakarta : PT Rajagrafindo Persada, 2012), h. 


\section{B. PEMBAHASAN}

\section{A. Pengaruh Teori Konvergensi dalam Pendidikan}

Konvergensi secara bahasa berasal dari bahasa Inggris dari kata converge yang artinya memusatkan pada satu titik, bertemu ${ }^{12}$ atau tindakan bertemu di satu tempat. Didalam kamus besar bahasa Indonesia konvergensi berasal dari kata konvergen, yang berarti bersifat menuju pada satu titik. ${ }^{13}$ Sedangkan didalam kamus psikologi konvergensi adalah interaksi antara faktor hereditas dan faktor lingkungan dalam proses perkembangan tingkah laku. ${ }^{14}$ Dari sini dapat ditarik sebuah pengertian bahwa konvergensi merupakan pertemuan dua variabel yang berbeda kedalam satu titik yang sama. Atau lebih tegasnya mempertemukan dua aliran yang berlawanan yaitu antara nativisme dengan empirisme kedalam satu ikatan yang sama.

Dalam dunia pendidikan konvergensi sangat berpengaruh, sehingga sampai saat ini teorinya masih sering digunakan. Karena Implikasi teori konvergensi dalam pendidkan yakni memberikan kemungkinan bagi pendidik untuk dapat membantu perkembangan individu sesuai dengan apa yang diharapkan, namun demikian pelaksanaannya harus tetap memperhatikan faktor-faktor pembawaan yang antara lain; kematangan, bakat, kemampuan, keadaan mental, dan sebagainya.

Kiranya teori konvergensi inilah yang cocok diterapkan dalam praktik pendidikan. Karena dapat diketahui, bahwa pendidikan merupakan lingkungan yang menjadi tempat terlibatnya individu yang saling berinteraksi. Misalnya bakat sebagai kemungkinan telah ada pada diri individu, akan tetapi bakat yang sudah tersedia itu perlu menemukan lingkungan yang sesuai supaya dapat berkembang. Apabila ia hidup pada lingkungan yang baik maka ia akan tumbuh dan berkembang menjadi anak yang baik dan sebaliknya apabila ia hidup pada lingkungan yang kurang baik maka ia akan hidup dan berkembang menjadi anak yang kurang baik pula. Sehingga lingkungan pendidikan yang di dalamnya terdapat para pendidik berperan penting bagi perkembangan anak karena pendidikan yang menentukan baik buruknya anak.

\footnotetext{
${ }^{12}$ John M. Echols, Hassan Shadily, Kamus Inggris Indonesia, (Jakarta: PT Gramedia, 2003), hal. 145.

13 Sampurna K, Sampurna, Kamus Lengkap Bahasa Indonesia, (Surabaya: Cipta Karya, 2003), hal. 242.

${ }^{14}$ J.P. Chaplin, terj. Kartini Kartono, Kamus Lengkap Psikologi, (Jakarta : PT. Grafindo Persada, 1981), h. 112
} 
Tanpa pendidikan anak tidak akan bisa berkembang karena pendidikan merupakan proses perkembangan bagi anak. Karena dapat dipahami, bahwa anak adalah makhluk hidup yang berkembang, ia masih muda dan perlu berkembang, ia juga membutuhkan rasa aman, pertolongan, dan hanya pada pendidik mereka dapat berkembang. Oleh karena itu, perkembangan pribadi sesungguhnya merupakan hasil proses kerjasama antara potensi hereditas (internal), dan lingkungan, serta pendidikan (eksternal). Interaksi antara pembawaan dan lingkungan (termasuk pendidikan) akan mencapai hasil yang diharapkan, apabila anak menemukan sendiri peranan seara aktif di dalam mencernakan segala pengalaman yang diperolehnya. Bahkan Menurut Djumransjah, teori konvergensi dalam pendidikan dapat disimpulkan sebagai berkut:

a. Pendidikan itu serba mungkin diberikan kepada anak didik

b. Pendidikan diartikan sebagai pertolongan yang diberikan kepada anak untuk mengembangkan pembawaan yang baik dan mencegah pembawaan yang buruk.

c. Hasil pendidikan tergantung kepada pembawaan dan lingkungan..$^{15}$

Dengan demikian dapat dipahami bahwa pembawaan dan lingkungan sebagai faktor yang ikut menentukan dalam proses pendidikan yang harus diketahui oleh para pendidik khususnya. Karena faktor tersebut terkadang menjadi penghambat dalam pendidikan. Dalam praktik pendidikan baik di lingkungan keluarga, sekolah maupun masyarakat, tujuan pendidikan yang hendak dicapai oleh masing-masing pendidik adalah berusaha mengembangkan potensi yang dimiliki anak didik sehingga terjadi perubahan perilaku. Oleh karena itu supaya tujuan pendidikan dapat tercapai, maka harus saling berhubungan dan bekerjasama dengan baik.

Keluarga merupakan lingkungan pertama bagi anak, di lingkungan keluarga pertama-tama anak mendapatkan pengaruh sadar. Karena itu bentuk dan isi serta caracara pendidikan di dalam keluarga akan selalu mempengaruhi tumbuh berkembangnya watak, budi pekerti dan kepribadian tiap-tiap manusia. Pendidikan dalam keluarga inilah yang akan digunakan oleh anak sebagai dasar untuk mengikuti pendidikan selanjutnya di sekolah. Sekolah sebagai lingkungan pendidikan kedua, bertugas mengembangkan potensi dan bakat anak didik agar mereka memiliki kecerdasan dan

\footnotetext{
${ }^{15}$ Jumransjah, Pengantar Filsafat Pendidikan, (Malang: Bayumedia, 2004), hlm. 61.
} 
keterampilan, yang kemudian diterapkan di tengah-tengah masyarakat. Karena Masyarakat sebagai lingkungan ketiga dan lingkungan yang akan mendidik anak dalam pergaulan sosial. Dalam hal ini, Agus Sujanto mengatakan bahwa "masyarakat sebagai lingkungan pendidikan ketiga merupakan tempat dimana seseorang menerapkan dan mengembangkan potensinya. Dalam perkembangan anak didik, selalu terjadi interaksi antara faktor ajar dan faktor dasar, faktor indogen dan faktor eksogen, faktor-ekstern dan faktor intern serta faktor lingkungan dan faktor pembawaan sebagaimana hukum konvergensi". 16

Dengan demikian masing-masing pasangan tersebut saling mempengaruhi. Akan tetapi dalam implementasinya ada yang mengganggap bahwa yang lebih dominan adalah faktor dasar (keturunan) atau pembawaan dari pada faktor lingkungan yaitu ahli-ahli psikologi konstitusional. Ada pula yang menganggap bahwa yang lebih berpengaruh dalam perkembangan anak adalah lingkungan. Pendapat ini banyak sekali pengikutnya terutama dari Inggris dan Amerika Serikat. ${ }^{17}$

Berdasarkan pengaruh konvergensi terhadap pendidikan maka Dengan demikian berdasarkan teori konvergensi ini, maka memberikan inspirasi kepada Ki Hajar Dewantara sampai kepada teori Trikonnya Yaitu :

a. Konvergensi : yang berarti pendidikan akan berhasil baik bila ada paduan antara faktor ajar dan faktor Dasar.

b. Kontinu : yang berarti pendidikan adalah usaha melanjutkan kelangsungan hidup manusia .

c. Konsentris: yang berarti pendidikan akan berhasil baik bila berpusat kepada kebudayaan bangsanya sendiri. ${ }^{18}$

Berdasarkan pandangan-pandangan diatas dapat disimpulkan bahwa dalam membentuk kepribadian anak teori konvergensi William stern memandang harus bersamaan antara heriditas dan lingkungan, dalam artian saling mendukung antara heriditas dan lingkungan. Tidak ada saling mengedepankan. Dengan begitu, para pendidik dengan adanya teori konvergensi ini, dapat mengetahui serta memahami kondisi peserta didiknya dengan melihat potensi yang dimilikinya, dan dikembangkan

\footnotetext{
${ }^{16}$ Agus Sujanto, Psikologi Perkembangan, (Jakarta : Rineka Cipta, 1996), h. 219.

${ }^{17}$ Disadur dari, Akyas Azhari, Psikologi Pendidikan, (Semarang: Bina Utama, 2003), h. 35.

${ }^{18}$ Agus Sujanto, op.cit, h. 61.
} 
dengan lingkungannya, sehingga perkembangan seorang anak yang diinginkan dalam dunia pendidikan dapat tercapai.

\section{B. Pandangan Pendidikan Islam Terhadap Teori Konvergensi}

Seperti yang telah diuraikan di atas mengenai konvergensi, bahwa konvergensi merupakan suatu aliran yang lahir dari hasil sintesis nativisme dan empirisme, yaitu Heriditas dan Lingkungan kemudian dipadukan oleh aliran Konvergensi menjadi satu. Dengan alasan bahwa ketika kedua faktor tersebut digabungkan maka proses pendidikan yang dilakukan akan berjalan dengan baik. Hal ini yang menjadi patron bagi para pendidik untuk melaksanakan proses pendidikan dalam dimensi kehidupan untuk mengembangkan kepribadian anak.

Sedangkan pada pembahasan pendidikan Islam, Dalam pendidikan Islam, kata pendidikan itu dikenal dengan tiga istilah yaitu al-tarbiyah, al-ta'lim dan al-ta'dib . Ketiga istilah itu diadopsi dari konteks al-Qur'an, karena pendidikan Islam, secara tekstual adalah pendidikan yang dilaksanakan berdasarkan ajaran-ajaran dan nilai-nilai Islam. Sedangkan ajaran dan nilai-nilai Islam itu bersumber dari al-Qur'an, hadits dan ijtihad. Sehingga dengan begitu kajian mengenai pendidikan Islam sebenarnya harus realisasi dari ajaran - ajaran al-Qur'an, Hadits dan Ijtihad. Dengan demikian Achmadi menegaskan bahwa "Pengertian pendidikan Islam tidak sama dengan pendidikan agama Islam. Dia menjelaskan bahwa pendidikan agama Islam hanya terbatas pada bidang-bidang studi agama seperti tauhid, fiqih, tarikh Nabi, membaca Al-Qur'an, tafsir dan hadist. Sedangkan pengertian pendidikan Islam lebih luas lagi, mengingat potensipotensi yang telah dianugerahkan Tuhan kepada manusia memang dipersiapkan untuk mengatasi berbagai masalah hidup dan kehidupan manusia yang begitu kompleks". ${ }^{19}$

Pandangan Achamadi yang mengungkapkan bahwa pendidikan Islam sangat luas maknanya, saat dicermati ternyata sangat relevan dengan term pendidikan yang diistilahkan di atas, karena saat diuraikan ketiga term di atas pasti terjadi interprestasi yang berbeda dan masing-masing memiliki konsep dan pandangan tersendiri dan lebih merujuk pada nilai-nilai Islam yang konteks nilainya bersumber dari al-Qur'an dan Hadits, sehingga dalam kajian mengenai Pandangan Pendidikan Islam terhadap teori Konvergensi, penulis akan melihat dari prespektif al-Qur'an atau Hadits.

\footnotetext{
${ }^{19}$ Achmadi, Islam Sebagai Paradigma Ilmu Pendidikan, (Yogyakarta: Aditya Media, 1992), h. 19-20.
} 
Dalam konteks pendidikan Islam, Pendidikan Islam melihat bahwa untuk mengembangkan kepribadian seorang anak berakar dari potensi rohaniah dan jasmania anak dalam kehidupan nyata ini. Pendidikan Islam memandang bahwa kehidupan kepribadian anak itu, harus dilihat dari pandangan Islam, sehingga Islam telah memberikan konsep pandangan bahwa perkembangan manusia diletakan pada posisi dua titik lingkaran, yaitu sebagai makhluk pribadi yang selalu mempererat hubungan dengan Allah dan sekaligus menjalin hubungan masyarakat. Dengan ikatan dalam dua lingkaran hubungan inilah, manusia menempuh rangkaian proses perkembangan yang menuju ke arah martabat hidup manusiawi sesuai dengan kehendak Tuhanya.

Pandangan Islam yang demikian inilah yang lebih bercorak Konvergensi dari pada empiris dan Nativisme karenan mengakui adanya pengaruh internal berupa keimanan dalam pribadi dan pengaruh eksternal yang berupa kegiatan sosial dalam bermasyarakat. ${ }^{20}$

Dengan demikian bisa dilihat firman Allah swt, sebagai pendukung dari konsep pandangan Islam tersebut :

Mereka diliputi kehinaan di mana saja mereka berada, kecuali jika mereka berpegang kepada tali (agama) Allah dan tali (perjanjian) dengan manusia. (Q.S Ali Imran:112). ${ }^{21}$

Pandangan ayat di atas, penulis dapat memahami bahwa yang dimaksud dengan berpegang kepada tali agama Allah dalam artian mempererat tali hubungan dengan Allah dan yang dimaksud dengan tali perjanjian dengan manusia yaitu memperat tali hubungan dengan sesama manusia. Sehingga ayat ini dapat difahami bahwa dalam pengembangan kepribadian, maka Anak harus mempunyai hubungan dengan Allah, dan Manusia. Yang dalam konteks ajaran Islam disebut sebagai Hablumminallah dan Hablumminannas (hubungan dengan Allah dan Hubungan dengan Manusia).

Inilah konsep pendidikan Islam yang ditawarkan oleh Islam, sehingga konsep Hablumminallah ini, akan melahirkan pada potensi keimanan, ketauhidan, keIslaman, keselamatan, keikhlasan, kesucian, kecenderungan menerima kebaikan dan kebenaran, dan sifat-sifat baik lainnya. Semua potensi itu bukan diturunkan dari orang tua, melainkan diturunkan oleh Allah swt sejak di alam perjanjian (mitsq). Proses

\footnotetext{
${ }^{20}$ Muzayyin Arifin, op. cit, h. 60

${ }^{21}$ Depertemen Agama RI, Al-Qur'an dan Terjamahnya, (Surabaya: Mekar, 2008), h. 106
} 
pemberian potensi-potensi itu melalui struktur ruhani. Oleh sebab itu struktur ruhani disebut juga fitrah al-munazzalah (fitrah yang diturunkan). ${ }^{22}$ Sesuai dengan firman Allah dalam Al Quran :

Dan (ingatlah), ketika Allahmu mengeluarkan keturunan anak-anak Adam dari sulbi mereka dan Allah mengambil kesaksian terhadap jiwa mereka (seraya berfirman): "Bukankah aku ini Allahmu?" mereka menjawab: "Betul (Engkau Tuhan kami), Kami menjadi saksi". (kami lakukan yang demikian itu) agar di hari kiamat kamu tidak mengatakan: "Sesungguhnya Kami (Bani Adam) adalah orang-orang yang lengah terhadap ini (keesaan Allah)". (QS. Al Araf: 172)23

Jadi secara potensial, kondisi jiwa manusia tidak netral, apalagi kosong seperti kertas putih. Namun secara aktual manusia tidak memiliki kebaikan atau keburukan yang diwarisi, kebaikan dan keburukan sangat tergantung pada realisasi pendidikan oleh anak (manusia) tersebut.

Sedangkan pada konteks Hablumminannas merupakan manifestasi dari hubungan manusia dengan lingkungannya, baik antara manusia dangan manusia, maupun dengan alam. Sehingga dalam kehidupannya, yang akan lebih berperan adalah potensi akal untuk berpikir, dengan demikian manusia mempunyai kehendak bebas dalam bertindak. Dengan begitu dalam menghasilkan kepribadian baik dan buruk, itu akan bergantung pada realitas kehiduapan yang akan dijalaninya. Sehingga dengan konsep inilah manusia akan disebut sebagai makhluk sosial.

Sebagai makhluk sosial, manusia butuh berinteraksi dengan orang lain, antara satu dengan yang lainnya, selain sebagai makhluk individu dan sosial, manusia merupakan makhluk Allah swt, maka hubungan vertikal dan horizontal tidak akan lepas dari etika yang telah ditetapkan oleh Allah swt. Begitu juga dengan individu manusia yang mempunyai potensi dasar (pembawaan) yang dapat mengarahkan pada keadaan baik dan buruk. Pada dasarnya anak adalah makhluk Allah yang dibekali kemampuan dan pembawaan yang beranekaragaman, maka dari itu pendidikan wajib menginsyafkannya, bahwa pada diri anak didik terdapat berbagai pembawaan yang wajib ia ketahui sendiri, ada yang baik dan ada yang buruk. Ia hidup dalam suatu lingkungan tertentu baik atau buruk, menguntungkan atau

\footnotetext{
${ }^{22}$ Noer Rohmah, Psikologi Umum, (Yogyakarta: Teras, 2012), h. 98

${ }^{23}$ Depertemen Agama RI, op.cit, h. 299.
} 
merugikan, pendidik wajib menimbulkan kesediaan dan semangat pada diri anak agar dengan kekuatan sendiri mampu berusaha mengembangkan bakat baik yang ada padanya dan meninggalkan lingkungan yang mengikat, karena dapat menghambat perkembangan baik atau dapat menyuburkan perkembangan bakat buruk. Ia wajib mencari lingkungan yang sesuai misalnya saja dalam pergaulan dengan teman. Ia wajib memiliki teman yang menguntungkan perkembangannya dan menjauhi teman yang menghambatnya.

Oleh karenanya di dalam pendidikan Islam pembentukan kepribadian dalam konteks Hablumminannas pada dasarnya adalah upaya untuk mengubah sikap ke arah kecenderungan terhadap nilai-nilai keislaman. Perubahan sikap tidak terjadi spontan, tetapi di antaranya disebabkan oleh adanya hubungan obyek, wawasan, peristiwa atau ide dan perubahan sikap harus dipelajari. Karena potensi Kepribadian manusia yang baik atau buruk sebenarnya sudah ditentukan Allah, tergantung manusianya itu, mau kepribadian baik atau buruk, hal ini sesuai Firman Allah

Dan jiwa serta penyempurnaannya (ciptaannya), maka Allah mengilhamkan kepada jiwa itu (jalan) kefasikan dan ketakwaannya, sesungguhnya beruntunglah orang yang mensucikan jiwa itu, dan Sesungguhnya merugilah orang yang mengotorinya. ${ }^{24}$ (Q.S. Asy-syams ayat 7-10)

Firman tersebut dapat dijadikan sumber pandangan bahwa usaha mempengaruhi jiwa manusia melalui pendidikan dapat berperan positif untuk mengarahkan perkembangannya kepada jalan kebenaran yaitu Islam. Dengan tanpa melalui usaha pendidikan, manusia akan terjerumus ke jalan yang salah atau sesat. Atas dasar ayat tersebut di atas kita dapat menginterpretasikan bahwa dalam fitrahNya manusia diberi kemampuan untuk memilih jalan yang benar. Kemampuan memilih tersebut, mendapatkan pengarahan dalam proses kependidikan yang mempengaruhinya. Jelaslah bahwa faktor kemampuan memilih yang terdapat di dalam fitrah manusia berpusat pada kemampuan berfikir sehat (berakal sehat), karena akal sehat mampu membedakan hal-hal yang benar dari yang salah. Sedangkan seseorang yang menjatuhkan pilihan yang benar secara tepat hanyalah orang yang berpendidikan sehat.

\footnotetext{
${ }^{24} \mathrm{Ibid}, \mathrm{h} .1164-1165$.
} 
Berfikir benar dan sehat adalah merupakan kemampuan fitrah yang dapat dikembangkan melalui pendidikan dan latihan. Sejalan dengan interpretasi tersebut, maka kita dapat mengatakan bahwa pengaruh faktor lingkungan yang disengaja yaitu pendidikan dan latihan berproses secara interaktif dengan kemampuan fitrah manusia. Berdasarkan uraian di atas jelaslah bagi kita mengenai pandangan pendidikan Islam terhadap teori Konvergensi. Pendidikan Islam melihat teori konvergensi dari dasar al-Qur'an dan Hadits. Dan lebih menekankan bahwa pembentukan kepribadian anak itu, terdapat intervensi dari Allah, sehingga bagi pandangan pendidikan Islam dalam pembentukan Kepribadian anak, ada 2 sumber yang sangat mempengaruhinya yaitu pertama bersumber dari Allah sebagai pencipta Potensi dan kedua manusia sebagai jalur dalam menciptakan lingkungan sosial yang baik antar sesama manusia.

Sedangakan pada konsep teori konvergensi yang dipelopori para ahli dalam hal ini yaitu William Stern bahwa teori konvergensi ini hanya berpatokan pada manusia saja, yang dapat membentuk kepribadian anak. Sehingga teori konvergensi dalam kajian pemikiran William Stern hanya berdasarkan antroposentris (berpusat pada manusia) dalam pembentukan dan pengembangan kepribadian anak. Sehingga anak diarahkan untuk mencapai kedewasaan dan kesejahteraan hidup di dunia. Sehingga menurut teori konvergensi pembentukan kepribadian adalah kerjasama yang baik antara faktor lingkungan dan faktor hereditas. Secara prakteknya dapat digambarkan bahwa supaya mempunyai kepribadian anak yang bagus, orang tersebut harus mempersiapkan keturunan yang bagus dan dilanjutkan dengan pemilihan lingkungan yang bagus pula.

\section{Relevansi teori Konvergensi dengan Pendidikan Islam}

Saat mencermati antara teori konvergensi dan pendidikan Islam, pada esensinya memiliki kesamaan dalam pembentukan kepribadian anak, walaupun pada dasarnya konvergensi lebih bercorak pada dasar humanistik (manusiawi) sedangkan pendidikan Islam lebih bercorak pada dasar ajaran Islamnya. Mengapa demikian, apakah konvergensi memiliki keterkaitan dengan pendidikan Islam ?. Hal ini dibuktikan dengan hadits Rasulullah saw :

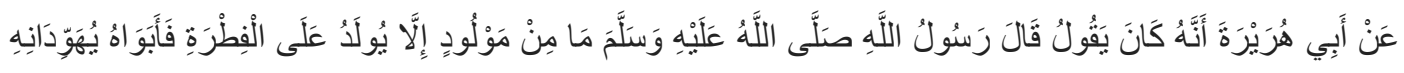

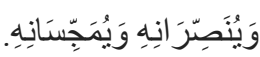


Terjamahnya :

Dari Abu Hurairah, dia berkata; "Rasulullah shallallahu 'alaihi wasallam telah bersabda: 'Seorang bayi tidak dilahirkan (ke dunia ini) melainkan ia berada dalam kesucian (fitrah). Kemudian kedua orang tuanyalah yang akan membuatnya menjadi Yahudi, Nasrani, ataupun Majusi (HR. Muslim No.4803) ${ }^{25}$

Hadits di atas, mendeskripsikan konsep pendidikan yang dilakukan dengan dua cara, yaitu heriditas dan lingkungan. Pertama, Konsep heriditas tercantumkan pada makna fitrah karena konsep fitrah ini banyak dari para pakar ilmuan Islam mengartikan sebagai potensi dasar yang dimiliki oleh anak sejak lahir, baik itu berkaitan dengan potensi agama, potensi akal, potensi kecerdasan maupun potensi ingin tahu. Dengan demikian konsep fitrah ini sebagai wujud anak yang dilahirkan bukan tidak memiliki apa-apa akan tetapi sudah diisi dengan bekal potensi. Terutama potensi agama. Sebagaimana Allah swt berfirman, dalam surah Arrum ayat 30 :

Maka hadapkanlah wajahmu dengan Lurus kepada agama Allah; (tetaplah atas) fitrah Allah yang telah menciptakan manusia menurut fitrah itu. tidak ada peubahan pada fitrah Allah. (Itulah) agama yang lurus; tetapi kebanyakan manusia tidak mengetahui. ${ }^{26}$

Fitrah Allah: Maksudnya ciptaan Allah. manusia diciptakan Allah mempunyai naluri beragama Yaitu agama tauhid. Oleh karena itu, kalau ada manusia tidak beragama tauhid, maka hal itu tidaklah wajar. mereka tidak beragama tauhid itu hanyalah lantara pengaruh lingkungan. Sejalan dengan itu, Quraish Shihab, mengatakan bahwa Kata "fitrah" terambil dari kata "fatharah" yang berarti mencipta. Maksudnya adalah mencipta sesuatu pertama kali, tanpa ada contoh sebelumnya. Dengan demikian kata fitrah dapat juga difahami dalam arti asal kejadian atau bawaan sejak lahir. ${ }^{27}$ Sehingga dari pandangan di atas, mengenai tentang fitrah agama atau potensi bawaan sejak lahir itu tidak akan berkembang tanpa ada dukungan dari faktor pendidikan yang dilakukan di lingkungan. Kedua, yaitu lingkungan. Faktor lingkungan

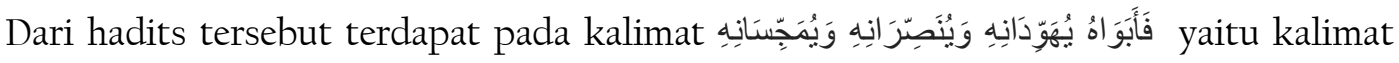
pendidikan yang dilakukan oleh orang tua. Karena dalam peran mendidik maka

${ }^{25}$ Abi Husain Muslim bin Alhajjaj bin Muslim Alqusairy Annisabury, Shohih Muslim No 2658, (DAR AL-GHAD AL-GADEED EGYPT-AL-MANSOURA,2007), h. 945.

${ }^{26}$ Depertemen Agama RI, op.cit, h.740-741.

${ }^{27}$ Quraish Shihab, Al-Misbah, (Jakarta: Lentera Hati, 2006), h.52. 
lingkungan keluarga salah satu aspek dari luar sebagai wujud dukungan pada pengembangan konsep fitrah (bawahan).

Dari ayat dan hadits tersebut menunjukkan bahwa pendidikan Islam secara implisit mempunyai relevansi dengan teori kovergensi, karena pada hadits dan ayat di atas menyinggung persolan heriditas (pembawaan) yang diistilahkan dengan kata fitrah dan di dukung pendidikan yang dilaksanakan dalam lingkungan keluarga. Dengan demikian antara teori konvergensi dan Pendidikan Islam memiliki relevansi yang sangat erat, karena pada hakekatnya keduanya membahas persolan pembentukan kepribadian anak berdasarkan pembawaan dan lingkungan.

Menurut Lawrence Meir Friedman, seorang ahli sosiologi hukum dari Stanford University, ada empat elemen utama dari sistem hukum (legal system), yaitu:

1. Isi Hukum (Legal Substance)

2. Struktur Hukum (Legal Structure)

3. Budaya Hukum (Legal Culture)

4. Dampak Hukum (legal impec)

Menurut Lawrence Meir Friedman berhasil atau tidaknya Penegakan hukum bergantung pada: Substansi Hukum, Struktur Hukum/Pranata Hukum dan Budaya Hukum. Pertama: Substansi Hukum: Dalam teori Lawrence Meir Friedman hal ini disebut sebagai sistem substansial yang menentukan bisa atau tidaknya hukum itu dilaksanakan. Substansi juga berarti produk yang dihasilkan oleh orang yang berada dalam sistem hukum yang mencakup keputusan yang mereka keluarkan atau aturan baru yang mereka susun.

Struktur hukum, yaitu kerangka bentuk yang permanen dari sistem hukum yang menjaga proses tetap berada di dalam batas-batasnya. Struktur terdiri atas: jumlah serta ukuran pengadilan, jurisdiksinya (jenis perkara yang diperiksa serta hukum acara yang digunakan), termasuk di dalam struktur ini juga mengenai penataan badan legislative.

Teori Lawrence Meir Friedman yang Kedua : Struktur Hukum/Pranata Hukum: Dalam teori Lawrence Meir Friedman hal ini disebut sebagai sistem Struktural yang menentukan bisa atau tidaknya hukum itu dilaksanakan dengan baik. Struktur hukum berdasarkan UU No. 8 Tahun 1981 meliputi; mulai dari Kepolisian, Kejaksaan, 
Pengadilan dan Badan Pelaksana Pidana (Lapas). Kewenangan lembaga penegak hukum dijamin oleh undang-undang. Sehingga dalam melaksanakan tugas dan tanggung jawabnya terlepas dari pengaruh kekuasaan pemerintah dan pengaruhpengaruh lain. Hukum tidak dapat berjalan atau tegak bila tidak ada aparat penegak hukum yang kredibilitas, kompeten dan independen. Seberapa bagusnya suatu peraturan perundang-undangan bila tidak didukung dengan aparat penegak hukum yang baik maka keadilan hanya angan-angan. Lemahnya mentalitas aparat penegak hukum mengakibatkan penegakkan hukum tidak berjalan sebagaimana mestinya. Banyak faktor yang mempengaruhi lemahnya mentalitas aparat penegak hukum diantaranya lemahnya pemahaman agama, ekonomi, proses rekruitmen yang tidak transparan dan lain sebagainya. Sehingga dapat dipertegas bahwa faktor penegak hukum memainkan peran penting dalam memfungsikan hukum. Kalau peraturan sudah baik, tetapi kualitas penegak hukum rendah maka akan ada masalah. Demikian juga, apabila peraturannya buruk sedangkan kualitas penegak hukum baik, kemungkinan munculnya masalah masih terbuka.

Masalah yang ditimbulkan dari struktur hukum yaitu sekarang banyak kasus penyelewengan kewenangan di ranah penegak hukum kepolisian yang banyak melakukan pelanggaran contohnya, banyak polisi lalu lintas yang menyalahi aturan seperti melakukan Tilang tapi akhirnya minta uang, dan melakukan pengoperasian tapi taka da surat izin dan lain sebagainnya. Sebagai Penegak hukum seharunya bisa menjadi wadah penampung aspirasi masyarakat ini malah menjadi musuh nyata bagi masyarakat, lihat saja sekarang masyarakat ak lagi mempercayai eksintensi penegak hukum di negri ini.

\section{PENUTUP}

Dalam membentuk kepribadian anak menurut teori konvergensi William stern memandang harus bersamaan antara heriditas dan lingkungan, dalam artian saling mendukung antara heriditas dan lingkungan. Tidak ada saling mengedepankan. Dengan begitu, para pendidik dengan adanya teori konvergensi ini, dapat mengetahui serta memahami kondisi peserta didiknya dengan melihat potensi yang dimilikinya, dan dikembangkan dengan lingkungannya, sehingga proses pembelajaran yang diinginkan dalam dunia pendidikan dapat tercapai. 
Sedangkan Pandangan pendidikan Islam terhadap teori konvergansi, berpatokan pada konsep Hablummiallah (hubungan dengan Allah), dalam artian bahwa Allah lah yang memberikan potensi awal dan Hablumminannas (hubungan dengan manusia) sebagai wujud perubahan kepribadian manusia dalam kehidupan sosial atau lingkungan. bahkan pembahasan teori Konvergensi dalam pendidikan Islam melihatnya dari faktor heriditas juga, akan tetapi berfokus pada konsep fitrah dan dikembangkan oleh lingkungan. Dengan demikian antara teori konvergensi dan Pendidikan Islam memiliki relevansi yang sangat erat, karena pada hakekatnya keduanya membahas persolan pembentukan kepribadian anak berdasarkan Pembawaan dan Lingkungan.

Keduanya mengakui pentingnya faktor heriditas dan lingkungan dalam membentuk dan mengembangkan kepribadian anak. Akan tetapi dari sisi lain, dalam pendidikan Islam kepribadian itu harus dibentuk dan dikembangkan sudah jelas yaitu ma'rifatullah (mengenal Allah) dan bertakwa kepada Allah bahkan Selain meyakini bahwa faktor internal (bawaan) dan eksternal (lingkungan) sangat berpengaruh dalam pendidikan, yaitu pembentukan kepribadian muslim yang berkualitas. Dalam Islam yang terpenting adanya hidayah dari Allah sebagai penentu keberhasilan dalam pendidikan. Sedangkan dalam pendidikan konvergensi yang berdasarkan antroposentris (berpusat pada manusia) pembentukan dan pengembangan kepribadian diarahkan untuk mencapai kedewasaan dan kesejahteraan hidup di dunia.

Teori Konvergensi dapat kita jadikan patokan dalam mengukur proses penegakan hukum di Indonesia. Aparat penegak hukum antara lain Polisi adalah bagian dari struktur bersama dengan organ jaksa, hakim, advokat, dan lembaga permasyarakatan. Interaksi antar komponen pengabdi hukum ini menentukan kokoh nya struktur hukum. Walau demikian, tegaknya hukum tidak hanya ditentukan oleh kokohnya struktur, tetapi juga terkait dengan kultur hukum di dalam masyarakat. Namun demikian, hingga kini ketiga unsur sebagaimana dikatakan oleh Friedman belum dapat terlaksana dengan baik, khususnya dalam struktur hukum dan budaya hukum. Sebagai contoh, dalam struktur hukum, Anggota polisi yang diharapkan menjadi penangkap narkoba, polisi sendiri ikut terlibat dalam jaringan narkoba. Demikian halnya para jaksa, sampai saat ini masih sangat sulit mencari jaksa yang benar-benar jujur. Karna masih banyak pelanggaran yang di lakukan oleh jaksa-jaksa 
yang ada di negri ini olehnya Teori Konvergensi menawarkan solusi bagi terciptanya aparatur yang bukan hanya taat hukum namun juga sadar hukum.

\section{DAFTAR PUSTAKA}

Abi Husain Muslim bin Alhajjaj bin Muslim Alqusairy Annisabury, 2007, Shohih Muslim No 2658, (DAR AL-GHAD AL-GADEED EGYPT-AL-MANSOURA).

Abudin Nata, 2012, Pemikiran Pendidikan Islam dan Barat, PT Rajagrafindo Persada, Jakarta. Achmadi, 1992, Islam Sebagai Paradigma Ilmu Pendidikan, Aditya Media, Yogyakarta.

Depertemen Agama RI, 2008, Al-Qur'an dan Terjamahnya, Mekar, Surabaya.

Agus Sujanto, 1996, Psikologi Perkembangan, Rineka Cipta, Jakarta.

Akyas Azhari, 2003, Psikologi Pendidikan, Bina Utama, Semarang.

Eva Latipah, 2012, Pengantar Psikologi Pendidikan, PT Pustaka Insan Madani, Yogyakarta.

J.P. Chaplin, terj. Kartini Kartono, 1981, Kamus Lengkap Psikologi, PT. Grafindo Persada, Jakarta.

Jalaludin dan Abdulllah, 2012, Filsafat Pendidikan, Ar Ruzz Media, Yogjakarta.

John M. Echols, Hassan Shadily, 2003, Kamus Inggris Indonesia, PT Gramedia, Jakarta.

Jumransjah, 2004, Pengantar Filsafat Pendidikan, Bayumedia, Malang.

Muhaimin dan Abdul Mujib, 1993, Pemikiran Pendidikan Islam, TrigendaKarya, Bandung.

Muhaimin, Suti'ah dan Sugeng Listyo Prabowo, 201l, Manajemen Pendidikan, Prenada Media Group, Jakarta.

Munarji, 2004, Ilmu Pendidikan Islam, PT Bina Ilmu, Jakarta.

Muzayyin Arifin, 2012, Filsafat Pendidikan Islam, PT Bumi Aksara, Jakarta.

Noer Rohmah, 2012, Psikologi Umum, Teras, Yogyakarta.

Purma Atmaja Prawira, 2013, Psikologi Pendidikan Dalam Prespektif Baru, Ar-ruzz Media, Yogyakarta.

Quraish Shihab, 2006, Tafsir Al-Misbah, Lentera Hati, Jakarta.

Sampurna K, Sampurna, 2003, Kamus Lengkap Bahasa Indonesia, Cipta Karya, Surabaya.

William Stern, 1914, The Psychological Methods of Testing Intelligence, Baltimore Warwick \& York, Inc, Breslau. 